\title{
INTEREST GROUPS AND THE “AMENDED” LIBERALIZATIONS OF THE MONTI GOVERNMENT
}

\author{
Liborio Mattina
}

The liberalization of public services is designed to generate economic growth and social progress. As far as the former is concerned, liberalization should help to reduce the very Italian imbalance between the average income of workers, which is among the lowest in Europe, and prices in the shops, which are among the highest. This imbalance is caused by the low productivity of services, which leads to higher prices, thereby lowering the purchasing power of workers and of companies. Liberalization should stimulate sector-level productivity and therefore lower prices, which in turn should increase citizens' purchasing power, to the benefit of the economy as a whole. ${ }^{1}$ As far as social progress is concerned, the liberalization of services should lead to the removal of corporate protectionism, privileges, and accrued status, and that ought to help create a more open, more inclusive, and fairer society. ${ }^{2}$

In the wake of the debate that has developed over the last 10 years, the policy of liberalizations in the services sector was launched by the center-left governments in the 13th (1996-2001) and 15th Legislatures (2006-2008) and partially reintroduced in the 16th Legislature by the center-right government. One of the first steps taken by the government led by Mario Monti was to initiate the decree law known as "Grow Italy," which was converted into Law No. 27/2012 on 24 March. The decree aroused interest within public opinion because the 
government put emphasis on policies that, albeit difficult to monitor, were heralded as leading to liberalizations and therefore to significant improvements within just a few years.

On an operational level, the Monti government accepted some recommendations from the Italian Competition Authority (ICA), adding measures with the aim of creating new jobs and keeping public spending down, or other initiatives that have very little to do with liberalizations. The result of all this is a rather incoherent set of policies dealing with a number of issues. This approach has prevented the government from focusing on the few key priorities that could have brought a significant shift of resources from protected assets to consumption and investment. The absence of a hierarchy of priorities led to the government "forgetting" the issue of the separation of the ownership of the SNAM gas network from the Italian National Petroleum Corporation (ENI), which, according to the statement issued by the undersecretary of the prime minister at the beginning of January 2012, was not one of the government's priorities. The reaction of the most influential opinion-makers in the media and of some political parties then led the government to hurriedly add the issue of the separation of the ownership of SNAM from ENI to the draft decree, and this turned out to be the measure within Law No. 27/2012 that had the greatest impact.

The assessments made by the Bank of Italy and by the economic observers cast doubt over the effectiveness of most of the policies contained within the "Grow Italy" law. Moreover, some of them required the issuing of further decrees by the ministries concerned, with new regulations that needed to be laid down in order to put them into effect. By the end of October 2012, only 23 percent of the measures had actually been implemented. ${ }^{3}$

Because of the limited space available in a single chapter, it is not possible to present an in-depth analysis of these measures. We would refer the reader to the overall picture presented in table 1 (see below), which shows each of the measures introduced for the various sectors and the amendments made by the Senate's Industrial Committee during its deliberations when the decree was being converted into law. The table also provides an assessment of the changes-both those that are pro-liberalization and those designed to maintain the status quo-brought about by the amendments that were passed.

After the following section, in which we shall consider some general points regarding the relationship between organized interests and decision-makers, the next two sections, which are dedicated respectively to the lobbying of the government and of Parliament, will look at the impact of the liberalization measures on the sectors and subsectors affected by the law and the extent to which organized interests 
promoted or obstructed the liberalizations introduced by the Monti government. The thesis put forward in this chapter is that the mobilization of interest groups made a significant contribution to ensure a modest outcome in terms of innovation for most of the measures contained within the "Grow Italy" law. Building on this premise, which we shall attempt to prove, in the concluding section we will make a few observations on the particular permeability of technocratic governments to the influence of organized interests.

\section{A Few Useful Concepts}

Organized interests become politically active in order to prevent or to press for certain public policies. It is public provision-either feared or requested - that mobilizes organizations that would otherwise limit themselves to operating in a pre-political sphere. ${ }^{4}$ Such mobilization can take place with an anti-cyclical function, that is, when organized interests call upon public institutions to support them in order to tackle an unfavorable economic situation. However, it can also come as a reaction to the introduction of regulations concerning the functioning of the sector or of the activities in which the mobilized interests are normally involved. In the case that we are examining, the mobilization was initially caused by the economic-financial crisis when it reached its peak in the summer of $2011 .{ }^{5}$ This then quickly became a "reactive" mobilization as soon as the Monti government began to make moves toward the liberalization of the services provided by public utilities. This reactive mobilization can lead those affected by the new regulations to work with the government to ensure that the measures being drawn up are in line with the objective of improving the way a certain sector functions. However, a reactive mobilization aims above all to maintain the status quo.

In a reactive mobilization, there are disagreements with the measures being prepared or taken, and these views are expressed through press releases and interviews in newspapers or on television. Organized interests may promote public events (conventions, conferences, meetings with the press) to cement internal cohesion and to bring public pressure to bear on policy-makers. They also make use of dissent and of public events to obtain access to legislators and to public administrators, outlining the reasons for their requests without attracting the attention of the media and without having to deal with opposing claims from competing interest groups. This is lobbying in its most traditional form, based on face-to-face relations between public decision-makers and representatives of organized interests. This tactic is 
frequently adopted because it is considered the most effective means of influencing the decisions made by legislators. Those who are representing interest groups act autonomously to establish direct links with decision-makers. If they are not able to do so on their own, they may request the mediation of political parties, which, depending on their electoral calculations and/or ideological affinity, take steps to introduce the representatives of organized interests to the relevant institutions.

The different ways that interest groups mobilize do not follow one another sequentially over a period of time; rather, they are more or less simultaneous. While they express, via the media, dissent with the steps taken by government, organized interests make every effort to build a strong, homogeneous position as they attempt to gain access to the legislative circuit, either directly or via the parties. The only time sequence that must be observed is that such access must precede the lobbying stage. It is for this reason that interest groups devote most of their energy to obtaining access to the legislative circuit and may resort to protests in the street when they realize that it is being denied. In the next few pages, we shall make a distinction between the mobilization of interest groups ex ante and ex post, and we shall explain why some have favored direct access to government departments while others have preferred the parliamentary arena to attempt to influence the outcome of the legislative process.

\section{Lobbying the Government}

Let us begin, then, by examining the case of interests that have easy access to government departments-without the need to go through the parties-when new legislation is still being drawn up. A good example of this is provided by the mobilization of the holding Anomina Petroli Italiana (API), which enjoys close relations with public administrators but which had been wrong-footed by news spread in early January according to which a draft decree on liberalizations was about to force oil companies to hand over 30 percent of the gasoline stations they own (equivalent to almost 98 percent of the pumps located in Italy). The ownership of gasoline stations enables the large companies to achieve a vertical integration of production and distribution, allowing them to maintain straightforward control of the price of gasoline and other fuels. The government denied that it was planning to introduce the measure, but this failed to quell API's concerns. The company's chairman spoke of the "demagogy of expropriation," which would lead to "the forced sale of a significant part of the installations, either to those running them or to goodness knows who." ${ }^{16}$ The negative reactions also focused 
on the proposal to permit gasoline station managers to purchase their supplies freely on the open market, avoiding the oil companies that owned the gasoline stations to which they were tied by binding contracts. The effect of this measure, according to Assopetroli, an association of wholesale oil producers, would ensure that "nobody would be able to guarantee the quality of the fuel, and this could lead to a proliferation of the illegal trading of gasoline." dissent in this way, the oil companies also set up private meetings with the minister of economic development in order to forestall the measures that they opposed. ${ }^{8}$ The outcome of these talks turned out to be in the oil companies' favor. The articles in the decree pertaining to the liberalization of the distribution of fuels had no provision for the handing over of gasoline stations that belonged to the oil companies. They also established that only 2 percent of gasoline station managers-that is, only those who owned their installations-would be permitted to obtain their supplies freely on the market and only for an amount not exceeding 50 percent of the fuel distributed in the previous year (see table 1). ${ }^{9}$

As far as insurance companies and the rail and motorway transport sector are concerned, we do not have details like those relating to API to show that their mobilization was geared mainly toward gaining direct access to government departments. However, there are at least two clues that suggest that this hypothesis may be correct. The first is that the measures introduced, or placed on hold, have largely reflected the expectations of the interest groups affected. The second is that the moves made by the relevant interest groups toward Parliament were geared toward less significant amendments of the regulatory system (see table 1 and below).

As an example of the first clue, we could take the case of the measure on motor vehicle insurance for civil responsibility, approved by the Senate, which turned out to be strongly biased toward upgrading the demand, although it was very bland as far as the supply was concerned. This means that it was largely designed to cater to the preferences of the insurance companies, which have always blamed the constantly rising premiums paid by motorists on the increase in fraudulent claims. ${ }^{10}$ Taking this interpretation into account, the new law introduces measures designed to prevent and stamp out fraud without, however, forcing the companies themselves to put more effort into its prevention. Above all, very little effective action was taken with regard to the supply side, in order to reduce the cost of premiums by increasing competition among companies in a sector that has oligopolistic characteristics that tend toward collusion. According to Article 34 of the law, the greatest competition should be the result of the obligation on insurance brokers to inform their clients, before a policy is 


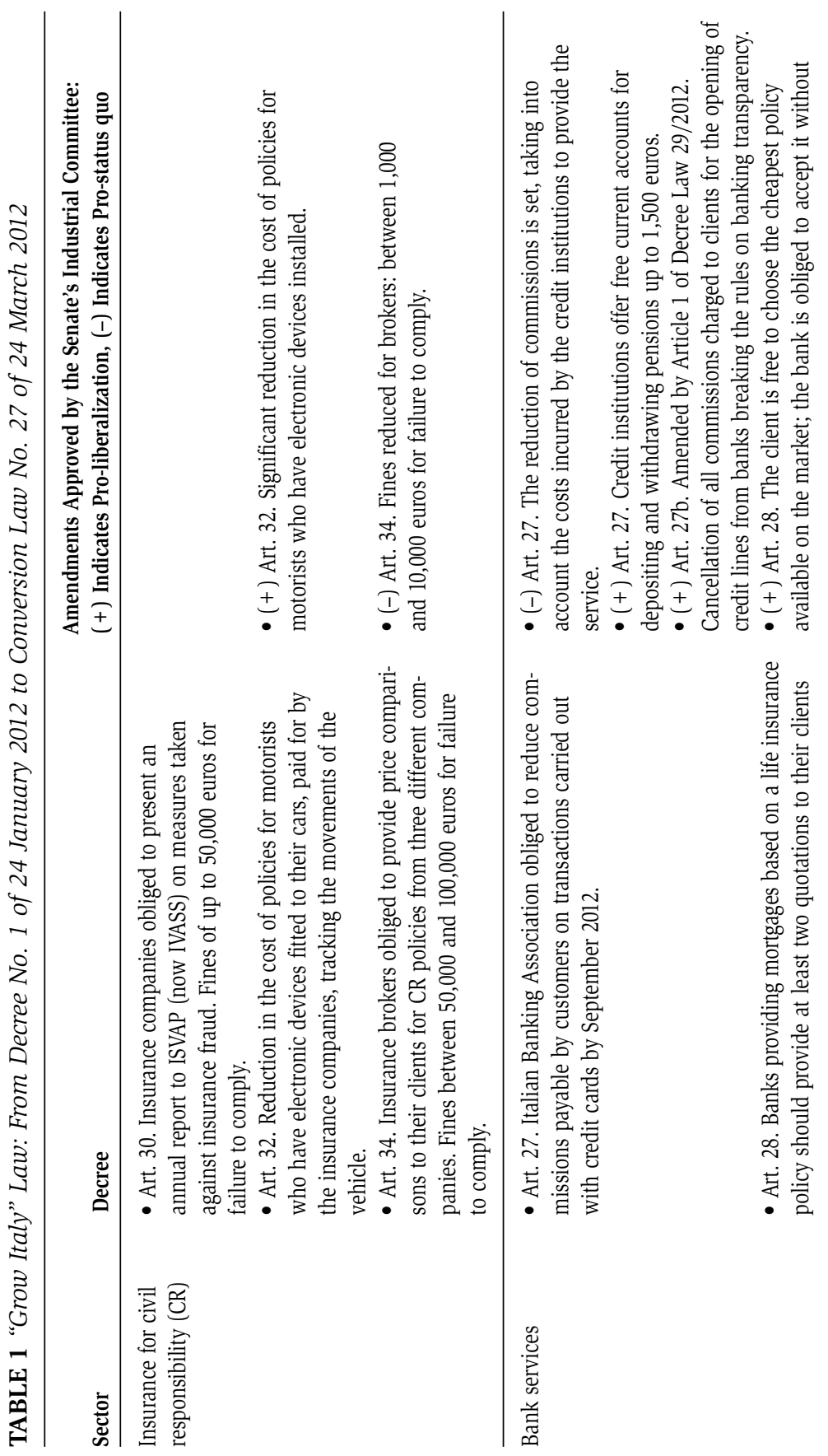




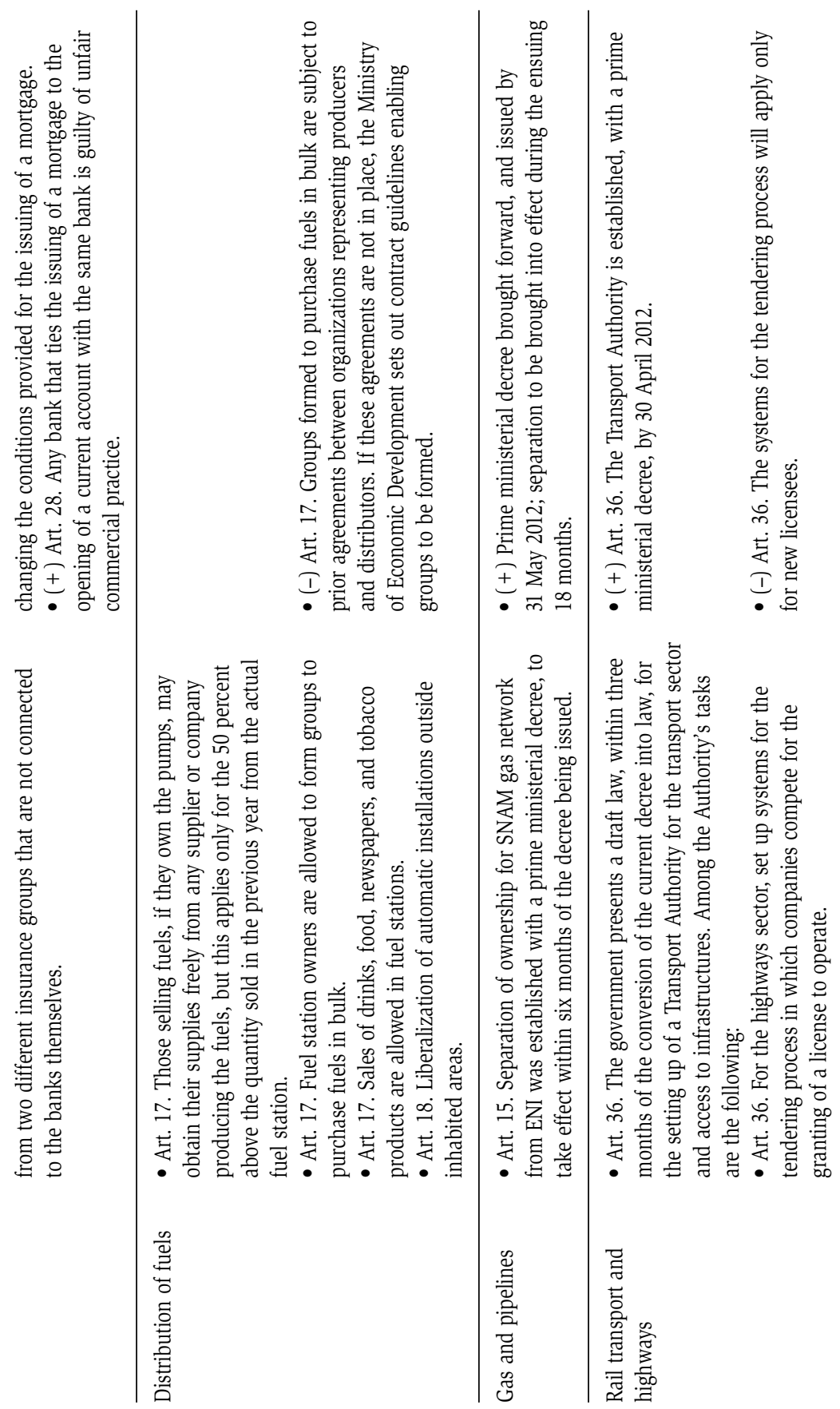




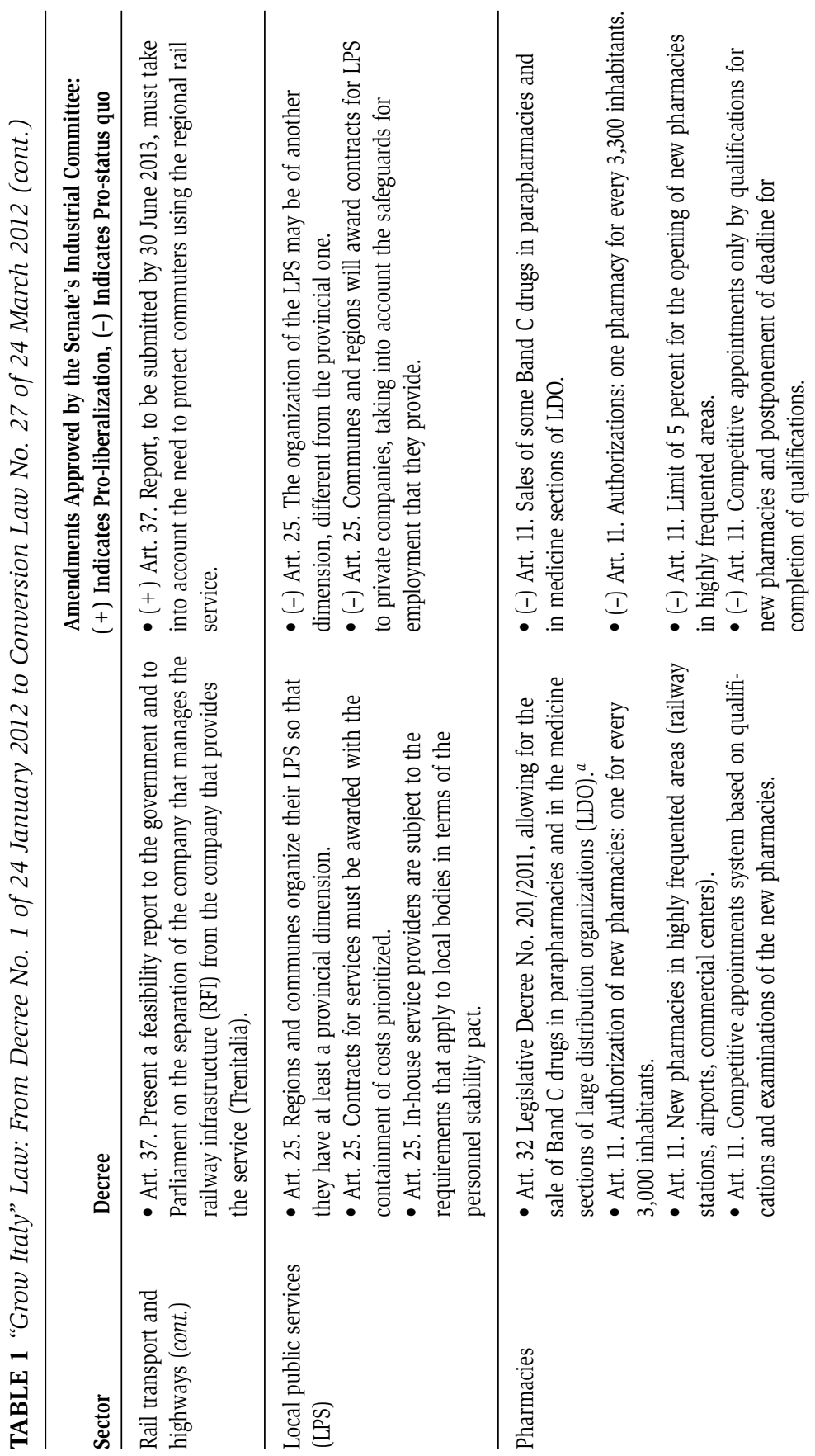




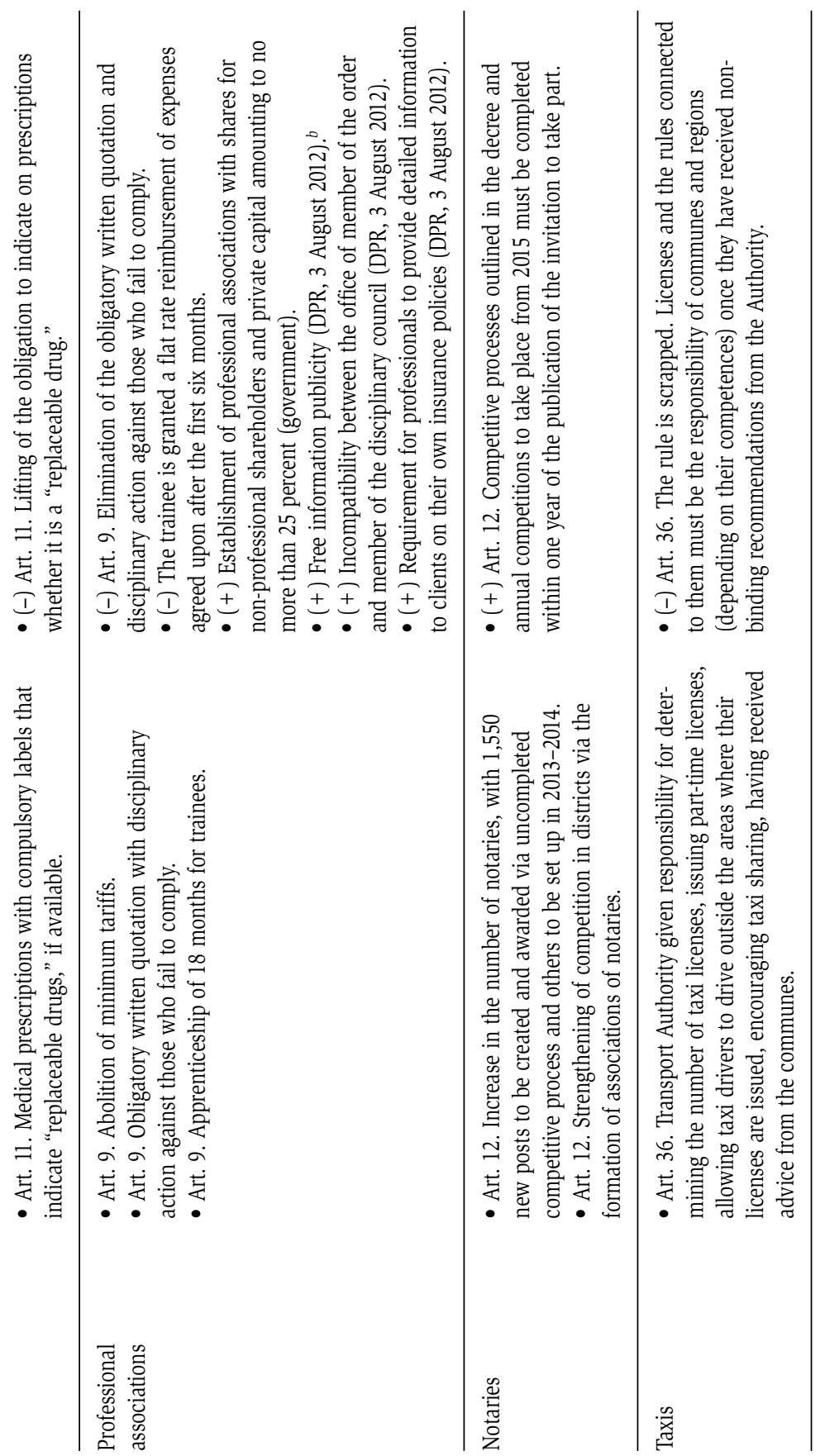




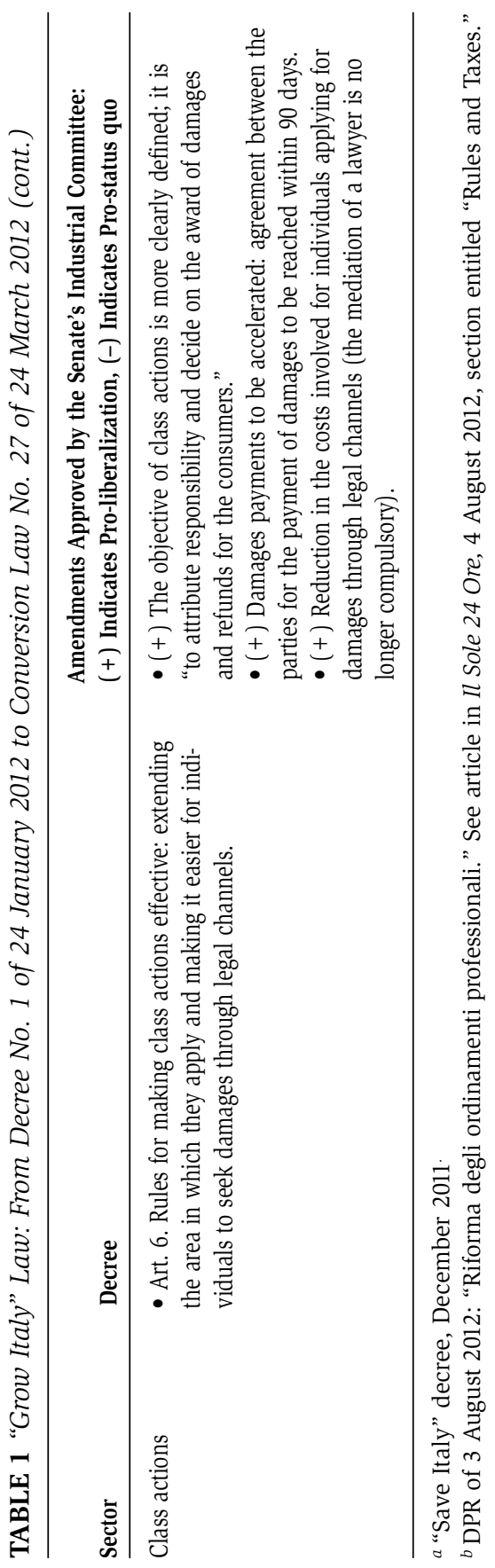


stipulated, on the charges set by at least three different companies belonging to different insurance groups. For this regulation to be effective, there was also, however, a call for at least one further rule alongside it designed to promote the development of agencies representing a number of companies. Without this rule, it is highly unlikely that insurance agents would provide information on a range of products, as they almost invariably represent a single insurance company and are therefore unable to sell the products that the rule on providing information set out to achieve. As a consequence, all of them would be prone to avoid providing comparative information.

As far as the rail transport sector is concerned, a bold and opportune step would have been to separate the rail network-owned by Ferrovie dello Stato through its subsidiary Rete Ferroviaria Italiana (RFI) - from the service, which is provided by the same company through its Trenitalia train network. Liberalization would enable RFI to remain as a regulated monopoly sector and Trenitalia as a competing service provider. ${ }^{11}$ Instead of launching this measure, the government preferred to pursue a more complicated path, handing to a proposed Transport Authority the task of carrying out a feasibility study on the separation of the network and the service. This solution was a concession to the senior management of Trenitalia, which has always been against the separation of the network from the service provider. The feasibility report on the separation was in fact handed to a Transport Authority that had not as yet been constituted and that, moreover, had already been expected to appear as part of the "Save Italy" decree in December 2011. Its ability to operate would depend on the resources that it was given and on its potential to stand up to political interference. Furthermore, it will still be some time before the terms for the delivery of the report are set out, and it will be the task of the government that opens the 17th Legislature to enforce this solution. The impression is that the Monti government, split internally on whether or not to make an immediate decision to separate the two parts of the rail sector, preferred to put the issue off to a later date. ${ }^{12}$ The whole matter, in a word, could end up being shunted to the sidelines.

The Transport Authority will also be called upon to intervene in the regulation of the highways sector. Here it will be a matter of setting tariff systems for the companies licensed to run them and the tendering processes that these companies will have to follow in order to reduce the duration of the licenses and to avoid hindering competition, which is currently restricted to times when a license is up for renewal and to the awarding of a license via a competitive process. These measures should help to reduce the dominant presence in the sector of Autostrade per l'Italia SpA, a private operator that controls 
75 percent of the proceeds with a contract for a long-term license. This operator, alongside other licensed companies (e.g., Gruppo Gavio and ANAS SpA), enjoys a privileged position. This can be gauged from the profits accrued, even during years of economic crisis, that are not attributable to investments in technology designed to lower costs or to increase demand. ${ }^{13}$

The measures set out in the law are innovative and have the potential to relax the rigid nature of the services that currently exist in the highways sector. Nevertheless, they are unlikely to take effect until the distant future because any change of the licensing system in the short term, given the fact that there are private contracts in place with companies quoted on the stock market, would lead to serious disputes between the state and Autostrade per l'Italia, the outcome of which would be hard to predict. In any legal battle, the company would be able to bring to bear its huge economic resources and the special relations it has built up with ministerial offices and most of the parties represented in Parliament. ${ }^{14}$ We will no doubt need to wait until 2038, when the contract between the state and Autostrade per l'Italia expires, before a more effective liberalization of the sector can take place.

As an example of the second clue mentioned above, the banks and the Italian Banking Association (ABI), which represents them, unlike the interest groups discussed earlier, have faced greater difficulties in protecting themselves ex ante during the legislative process leading to liberalizations, despite the fact that the ABI belongs to a small group of organized interests that have special access to government bodies. ${ }^{15}$ The recent difficulty that Italian banks have experienced in achieving representation in the highest offices of public institutions is the result of their growing unpopularity. This has come about in part because of the operating costs of the banks, which are among the highest in Europe and which fall mainly on savers. ${ }^{16}$ The adverse climate of public opinion was made worse by the financial crisis in 2007-2008 and by the sovereign debt crisis that followed, which was in turn attributed by public opinion, rightly or wrongly, to the banks.

The poor reputation of credit institutions led both the government and the parties to distance themselves temporarily from the banks. An example is what took place in the Senate when the "Grow Italy" decree was being converted into law. The Senate Finance Commission passed an amendment that canceled all the bank commissions against the concession of credit lines for their clients. This measure put the private nature of the credit institutes under the spotlight. Had it been adopted in the final version of the law, it would have caused very high financial costs for the banks. The ABI reacted to the measure with the resignations of its president and executive committee members. ${ }^{17}$ Once 
the government and Parliament became aware of the difficulties that the banks would face if the law were to be put into effect, they proceeded to amend it, seeking, however, to shift the burden of the initiative from one side to the other. In the end, a solution was found that involved shared responsibilities. The Chamber of Deputies approved a motion requiring the government to issue a decree law providing for the cancellation of commissions, but only for those institutions that have not subscribed to the government rules on banking transparency.

This episode indicates that legislators adopt policy choices that may go against the wishes of the business community when they realize that those wishes are in conflict with the prevailing attitudes of the electorate, whose votes they rely upon to be re-elected. As far as Monti's technocratic government is concerned, its distancing from the banks shows a need to avoid any semblance of being under their control and thereby avoid being labeled as the "government of the banks."

We shall conclude this circumstantial survey of the broad convergence that appeared "upstream" between the steps taken by the government and the expectations of large interest groups with a few observations on the liberalizing measures adopted for the natural gas market. One of the main problems of the gas market in Italy stems from the monopolistic running of the network by ENI, via the SNAM gas network that it controls. This allows the main producer and importer of gas to determine the total quantity of gas to be imported and the amount that may be imported by its competitors. ${ }^{18}$ To increase competition among operators, the measure contained in the decree established the separation of ownership between SNAM and ENI. This was welcomed by the chief executive of ENI, who had become "worn down" by the demands made over a number of years from the business world, from the scientific community, and from the political class about the need for separation and thus had been prepared for the inevitability of the measure. For its part, ENI expects to maximize its revenue from the sale of its majority holding in SNAM and believes that the measure will allow it to operate in the gas market with greater autonomy. ${ }^{19}$ The measured reaction of ENI to the government's decision was probably also a result of the fact that, for at least some years, the liberalization of the gas delivery market will not enable its rivals to become more competitive, since they have a much weaker bargaining position than ENI in negotiations for the purchasing of natural gas from large foreign suppliers. ${ }^{20}$ In any event, the separation will not have immediate beneficial effects on the cost of gas for consumers as the upward and downward variations in prices depend on the cost of the raw materials and of the amortization of infrastructure, not to mention the impact of taxes. 


\section{The Lobbying of Parliament}

Before proceeding to look at the lobbying of Parliament, it is worth remembering that, according to the Italian Constitution, any law proposed by the government must go to Parliament for final approval. This approval is often granted only after the bill has been amended, sometimes significantly, by the permanent committees and by the floor. When the law is being drawn up, the government may work autonomously or it may decide to consult representatives of interests affected by the proposed legislation in order to be fully aware of any counter-arguments. This "preventive consultation" is widely found in modern democracies. In some countries, it is institutionalized, while in Italy it is not. After being installed, the Monti government ruled out the idea of preventive consultations with organized interests, deciding instead simply to inform those affected by the new regulations and then, after listening to them, to make whatever decisions it deemed necessary. This approach, however, was undermined by the lobbying of the government that was carried out by the large organized interests, as we saw in the previous section. This put the government on a collision course with some of the interests directly affected by the measures designed to liberalize services, which tried to influence the legislative process, particularly through parliamentary lobbying.

One significant example of this was the controversy that sprung up with Federfarma, a body representing 16,000 pharmacy owners, which took action to oppose articles in the "Save Italy" decree allowing for the sale of Band $\mathrm{C}$ drugs (i.e., those requiring a doctor's prescription but not reimbursed via the national health service) in "parapharmacies" and in the medicine sections of large distribution organizations. The government's reluctance to change this measure led Federfarma to seek the support of the People of Freedom (PdL) parliamentary groups, ${ }^{21}$ which tried to dissuade the government by sending a letter to the prime minister that had been signed by 73 MPs, including the leaders of the PdL groups in the Chamber and in the Senate, and by some ex-ministers from the previous Berlusconi government. ${ }^{22}$ The letter described the liberalization of Band $\mathrm{C}$ drugs as a "very serious sign of unreasonableness" and called upon Monti to scrap the measure, using a courteous but peremptory tone.

The prime minister ignored the letter and sent the unchanged text of the decree to the Finance Committee of the Chamber, which is responsible for examining the government's legislative proposals. At the Committee stage, the PdL members succeeded in pushing through an amendment rescinding the liberalization of Band $\mathrm{C}$ drugs. The government's reaction was one of surprise and consternation, but it 
took note of the fact that Parliament would have an important role to play in the whole issue of liberalizations. ${ }^{23}$ As far as Band C drugs were concerned, the government was forced to accept a much tamer solution, which was then adopted by the Industrial Committee of the Senate with an appropriate amendment to the "Grow Italy" decree (see table 1).

Having learned a lesson from this clash with Federfarma, the government took a more conciliatory position in negotiations with the associations representing the regulated professions when the time came to send the decree to the Finance Committee. There are currently 28 regulated professions, and their number is on the rise. ${ }^{24}$ They represent around 1.3 million people, that is, 5.8 percent of the workforce and 28 percent of employees with university qualifications. ${ }^{25}$ The first drafts of the decree set out to remove many of the outdated practices that are typically found in the professions. However, the government soon became aware that it did not have the necessary majority in the Committee to be able to push through the liberalization measures for the professions. Consequently, the executive took the initiative and presented its own amendments in an attempt to keep the substance of the original bill, while taking into account the wishes of the majority of the members of the Committee.

The main characteristics of the final version are shown in table 1, which also lists the measures that followed after the approval of the prime ministerial decree (DPR) regarding the reform of the regulated professions. As the table shows, the law brought in a number of innovations. Nevertheless, the new regulations provide no protection for the minimum rights of those entering the professions through internships (e.g., a fair salary). Furthermore, they offer few advantages to citizens, because an amendment canceled the requirement for a professional person to give his or her client a written quotation, as set out in the government's decree, when agreeing to take on a task. Similarly, it cannot be taken for granted that citizens will benefit from the abolition of "minimum tariffs," which laid down rigid lists of charges for professional services, thereby preventing clients from choosing among competing offers. In spite of the fact that they were abolished, minimum tariffs have been reintroduced de facto through Article 9 of the Conversion Law, which sets out "standard" remunerations for all professional services carried out by a jurisdictional body (e.g., courts). ${ }^{26}$ Minimum tariffs have also been reintroduced in the draft law relating to the reform of the forensic profession. This reform was strongly criticized by the ICA because, by bringing back tariffs, prolonging internships, and discouraging competition, it clearly goes against whatever limited progress had been made toward regulating the professions. ${ }^{27}$ 
Initially, the Monti government had also shown an unwillingness to engage in consultations with the unions representing taxi drivers. The mobilization of this group has been marked by ongoing street protests. Drawing support from the center-right parliamentary groups, the mobilization of taxi drivers had already had the effect of reducing the impact of the liberalization measures for the sector that had been approved by the center-left government in $2006 ;{ }^{28}$ of neutralizing the attempt to liberalize made by the minister of the economy, Giulio Tremonti in August 2011; and of scrapping the rules on taxis in the "Save Italy" decree of December 2011.

Protests are a form of mobilization that can sometimes isolate the interest groups that organize them. But the taxi drivers' unions, which represent 30,000 recognized workers (and an additional 10,000 who are non-unionized and unauthorized), succeeded in avoiding the risk of being isolated, unlike Monti's government. Their protest was actually viewed sympathetically by both right-wing and left-wing mayors of some of the major cities. Further public support for their struggle came from the Italian General Confederation of Labor (CISL), the PdL, and, surprisingly, even from some within the Democratic Party (PD), which accused the government of starting "from the lowest levels," with taxi drivers and pharmacists, striking a blow "not where it is fair but where it is easier." 29 Similar opinions were expressed in most of the leading newspapers, and this finally led to the government issuing a document, agreed upon jointly with the taxi drivers' unions, that accepted most of the demands made by the taxi drivers. This document opened the way, at the committee stage, for the measures relating to the "white cars" to be substantially revised. The government forwarded the original text of the decree, but it handed over responsibility to the committee for amendments, with the provision that the decree should at least preserve the regulation of the sector for the new Transport Authority. In reality, even that directive was not applied: the role of the Authority was reduced to giving an opinion, on a merely consultative basis, about measures to be determined by communes and regions.

In the three cases that we have examined, the final version of the new law was significantly modified by representatives of parties in the Senate Committee, due to the fact that different majorities had been formed from the majority that had passed a confidence vote in the technocratic government when it had been installed. The amendments to the government's initial text were drawn up as a result of precise political choices, with a view to maintaining the status quo. This outcome was welcomed by the organized interests that had protested. We shall look again at this matter in the next section. For now, let us make 
some concluding comments on the lobbying of Parliament concerning the measures contained in the "Grow Italy" law by examining the local public services.

There was no mobilization in this area. In fact, the decree singles out regions and local governments run by political parties, that is, by the same actors who, in committee, had to approve or amend the measures introduced by the government. In this case, the legislator and those affected by the new law were, for the most part, one and the same person, creating a possible conflict of interest in those called upon to make decisions. In this particular case, the legislator was supposed to ensure the provision of good, convenient services to the local communities through the rules on local authorities and on the companies that they had holdings in. At the same time, the legislator-to the extent that she or he was party-based-was called upon to take account of the companies and their employees who were responsible for providing these services, given that both of these were often closely linked to political parties, which do not always award the provision of services using the criteria of profitability and efficiency.

The decree's provision on local public services did not set out to move toward liberalization as it is normally understood. It simply aimed to keep costs down, obliging regions and local governments to ensure that the companies contracted to provide services for them, and especially in-house services, stay within the limits laid down by the Stability Pact. ${ }^{30}$ To meet that objective, the decree also encouraged growth in the business dimension of public companies in order to reduce the fragmentation of supply and thereby promote economies of scale.

An analysis of the amendment passed by the Industrial Committee of the Senate reveals that the representatives of political parties worked out a flexible reinterpretation of the rule. The amendment establishes that the optimum size for companies providing services should normally have a "provincial" dimension, but it allows for local authorities to retain companies with a "commune" dimension. Furthermore, it stipulates that local bodies will have to award their public services to companies that commit to "adopting means to protect jobs." This seemingly laudable preference can, however, lead to the retention of oversized bodies that are loyal to parties, and these often bring influence to bear on the recruitment of workers in the companies that they control. It is well-known, indeed, that local services, especially in less highly developed areas of the country, have served largely to create jobs and that their debt levels and low efficiency have been justified because they have contributed to creating social stability (albeit a precarious one), as well as providing reservoirs of electoral consensus. ${ }^{31}$ 
Finally, we note the significant improvements with regard to the conditions for engaging in class actions. This was made possible by the amendments approved at the committee stage upon an initiative taken by PD senators. ${ }^{32}$

\section{Conclusion: The Monti Government's Susceptibility to Organized Interests}

Having completed our analysis of the lobbying of government and Parliament, we are in a position to draw a few brief conclusions. The technocratic government presented some new elements that distinguish it from governments formed by parties, the most obvious of which are that it originated outside of Parliament and that its ministers have no party affiliations. Nonetheless, it operated within the institutional and political boundaries that characterize parliamentary democracies. Of the various constraints that it was bound by, we have examined the mobilization of organized interests, whose primary aim is to maintain the status quo. The government proved to be susceptible to lobbying carried out by large organized interests ex ante (oil companies, railways, highway licensees, insurance companies) because these big organizations-among which we should obviously include ENI and the banks, even though they kept a low profile as far as the question of the liberalization of services was concerned-provide essential services to the general public, either as natural monopolies or as oligopolies. In view of the specific service that they provide, these interests have to establish direct and ongoing relations with the government and with ministries, thereby taking the status of "insiders." This means that those in power consider them legitimate and consult with them on a regular basis because their needs are looked on as a priority if the quality and continuity of vital public services are to be safeguarded.

The major suppliers of public services make good use of their close relations with those in government, taking steps-before the legislative process gets under way-to protect their own interests within the context of the government's plans for new legislation. For this reason, they are less visible in the parliamentary arena compared to interests that do not have direct access to the government. But the insiders do not disregard Parliament. They view it as another important arena in which to intervene in order to push for changes to regulations that can always be "improved."

It is in this light that the case of API should be seen. API had some success in hampering joint agreements among distributors for the bulk purchasing of fuels. An amendment approved by the Industrial 
Committee established that the creation of any cooperative groups must be subordinate to the agreements reached with the oil company associations (table 1). However, the associations of distributors were unable to reach an agreement with them. Another case that is worth mentioning is the campaign organized by insurance companies, which took action in Parliament in order to weaken the impact that sanctions contained in Article 34 of the decree would have on them. These sanctions would have involved large fines for brokers who failed to provide a comparative quotation for various policies for civil responsibility. This campaign succeeded, thanks to the collaboration of senators who approved an amendment in the Industrial Committee that drastically reduced the level of the fines (table 1). Another noteworthy example is the amendment that the Industrial Committee passed confirming that the regulatory powers of the Transport Authority in the highways sector would apply only to new licensees (table 1).

Parliament proved to be decidedly more important as far as the lobbying carried out by pharmacists, taxi drivers, and those representing the liberal professions is concerned. Their decision to lobby Parliament was based on the fact that the strongest cards that they could play were the exercising of their right to vote and the funds they could provide for candidates in electoral campaigns. These resources are of no value when trying to influence a government made up of experts who, in most cases, have no political ambition. They are, however, highly valued by politicians within the parliamentary groups, as they can prove useful to those MPs who wish to stay on and to further their political career. This explains why the organizations we surveyed above found parties in Parliament that were willing to take the steps required to amend articles in the "Grow Italy" decree in response to their wishes.

The choice of the PdL as the main party to target was based on the fact that the organizations concerned represent social groups that normally vote for the center-right parties. As the largest party within the center-right, the PdL was in a stronger position to build parliamentary majorities that would be able to annul or modify articles in the "Grow Italy" decree that were unwelcome to the groups that had mobilized. These interests decided to ignore the PD, as it had been considered the liberalization party ever since the mobilization of the summer of 2006 had taken place.

The success of the lobbying of Parliament carried out by organized interests, a result of mediation with the parties, enables us to make a more general point about the problems of coherence between a proposed law and the final outcome that can exist when there is a technical government. The different origins of the members of the government and the parliamentary majority can bring a negative influence 
to bear on the legislative process. This difference can, in fact, lead to fundamental tensions between the experts, whose aim is to approve measures required to make a strong impact to overcome pressing difficulties, and the members of the parliamentary majority, who fear the negative political reaction of citizens directly affected by the government's measures. There is one further factor that must be added as a reason for the poor level of cohesion between a technical government and the parliamentary majority. This is the composition of the parliamentary majority itself, which is made up of parties that under normal circumstances would be competing with one another and that only temporarily recognize that they have a common interest-to avoid taking direct responsibility for unpopular, yet necessary, policies. This majority is by definition lacking in consensus because the competition between the parties that compose it still persists, albeit in latent form. This rivalry manifests itself in the attempts that each party makes to lighten, as far as possible, the loads that the unpopular measures create for the segments of the electorate that are most loyal to them, and to shift these loads onto the supporters of the competing parties.

In such a situation, a technical government's ability to keep its parliamentary majority under control is somewhat flimsy, and the efficacy of the policies it introduces will largely depend upon whether or not compromises can be found for each solution that may go against the various and often contrasting preferences of the parties that make up the majority. In these conditions, the legislative process becomes rocky, as the majority groups take corrective actions between the first draft of a law and the final version. There is competition within the groups themselves, and they have plenty of elbow room to weigh up the government's priorities and are thus able to introduce significant modifications to the draft laws drawn up by the government. In a word, the uncertainties surrounding the trustworthiness of the parliamentary majority leave the technical government open to the influence of lobbying from interests. The end result is that the outcome of the legislative process can be the introduction of regulations that, while keeping their original purpose intact, in reality are transformed to a significant degree as the law passes through Parliament. During the stage when it was converted into law, even the "Grow Italy" decree underwent a similar transformation, ensuring advantages for the interests that had mobilized in order to maintain the status quo. 
Liborio Mattina is full a Professor at the University of Trieste, where he teaches Political Science.

\section{Notes}

1. Italian Competition Authority, Relazione annuale sull'attività svolta, April 2008, 5.

2. M. Monti, “Tensioni nella maggioranza,” Corriere della Sera, 1 May 2011.

3. "Riforme, attuazione al 17,4\%," Il Sole 24 Ore, 2 November 2012.

4. This point is developed further in L. Mattina, I gruppi di interesse (Bologna: Il Mulino, 2010), 14ff.

5. On the anti-cyclic mobilization of interests during the summer of 2011, see L. Mattina, "Sfide e prospettive per le organizzazioni imprenditoriali in Italia,” Quaderni di Rassegna Sindacale 12, no. 4 (2011): 91-115.

6. "Intervista a Ugo Braghetti Peretti: No all'esproprio sui carburanti, rischio boomerang sui prezzi,” Il Sole 24 Ore, 18 January 2012.

7. G. B. Bozzo, "Il Governo tratta anche su carburanti e ferrovie: Il ministro Passera al lavoro per venire incontro a Fs e compagnie petrolifere," Il Giornale, 15 January 2012.

8. Ibid. See also P. Foschi, "Da avvocati, tassisti e petrolieri i primi dubbi sul 'Piano Passera,'” Corriere della Sera, 9 January 2012.

9. A. Baccaro, "Benzina prezzi più chiari: 'Gogna' online antitruffe," Corriere della Sera, 21 January 2012.

10. D. Porrini, "Rc auto: La liberalizzazione qui non c'è,” http://archivio. lavoce.info/articoli/pagina1002935.html, 13 March 2012.

11. Cf. Carlo Scarpa, "Il trasporto ferroviario: L'alba di una riforma," in Politiche di liberalizzazione e concorrenza in Italia, ed. F. Pammolli, C. Cambini, and A. Giannaccari (Bologna: Il Mulino, 2007), 192-196.

12. A. Signorini, "Poste, treni, negozi e art. 18: Quante misure finite nel cassetto," Il Giornale, 22 January 2012.

13. M. Ponti, "L’agenda dell'Autorità dei trasporti," Consumatori, Diritti e Mercato, no. 2 (2012): 41.

14. Ibid.

15. Mattina, "Sfide e prospettive," 98-99.

16. C. Milani, "Commissioni bancarie battaglia risolta: Il nodo resta il costo," La Repubblica-Affari Finanza, 26 March 2012; G. Cespa, "Banche e mercati finanziari: Sviluppi recenti e proposte di intervento," in Pammolli et al., Politiche di liberalizzazione e concorrenza in Italia, 310-315.

17. R. Bagnoli, "Emendamento sulle banche: Si dimettono i vertici Abi," Corriere della Sera, 2 March 2012.

18. R. Creatini, "Il settore dell'energia: Come liberalizzare in modo energetico?" in Pammolli et al., Politiche di liberalizzazione e concorrenza in Italia, 65-101. 
19. F. Massaro, "Pronti a vendere tutta la Snam," Corriere della Sera, 21 January 2012.

20. L. Pagni, "Dalla rete separate tariffe più basse: Ma per gli effetti servirà molto tempo," Corriere della Sera, 21 January 2012.

21. The president of Federfarma openly thanked the PdL leader for the support given for the pharmacists' plight, stating that, as a result of it, she was confident about the positive outcome of Federfarma's talks with the government: "I am convinced that they will listen to us ... I am certain." See R. Turno, “Farmacie: Identità a rischio,” Il Sole 24 Ore, 15 January 2012.

22. See http://www.quotidianosanita.it/allegati/allegato3703200.pdf (accessed 7 May 2012).

23. A. Gentili, “Catricalà: A gennaio una legge per le liberalizzazioni,” Il Messaggero, 16 December 2012.

24. R. Cappello, Il cappio (Soveria Mannelli: Rubettino, 2010), 44-45, 52.

25. Ibid.

26. V. Conte, "Liberalizzazioni, i dubbi di Bankitalia," La Repubblica, 2 February 2012.

27. G. Negri, "Antitrust: Legali anticoncorrenza. La proposta di parcelle modellate sui parametri nasconde il ritorno alle tariffe," Il Sole 24 Ore, 11 August 2012.

28. On this point, please see A. Lirosi and E. Cinotti, L'Assedio: Il difficile cammino delle liberalizzazioni a favore del cittadino-consumatore (Rome: Aliberti Editore), 95-99.

29. L. Landò, “Non solo Taxi,” L'Unità, 14 January 2012.

30. Regions and local authorities hold control over the in-house service companies in a way that is similar to how control is exercised over their own services.

31. The available data are incomplete but of general significance. They show that in 2011 the companies in which councils had holdings accumulated losses amounting to over 943 million euros. On this, see C. D'Aries and E. Bracci, "Maggiore efficienza se entrano i privati," Il Sole 24 Ore, 29 October 2012.

32. Press release of the Democratic Party, "Liberalizzazioni, Lirosi: 'Da proposte PD rafforzata tutela consumatori,” 23 February 2012, http://www. partitodemocratico.it/doc/231296. 